\title{
Evaluation of selected physico-chemical, colour and textural characteristics of market Gulabjamun
}

\author{
VN Sukre, P Barnwal, BB Chavhan, A Deep and PN Bhagat
}

Received: 12 May 2021 / Accepted: 10 October 2021/ Published online: 22 December 2021

(C) Indian Dairy Association (India) 2021

\begin{abstract}
Gulabjamun is one of the most popular traditional Indian dairy products. The various characteristics such as physico-chemical, colour and textural quality characteristics of six brands of Gulabjamun were investigated which plays important role in its marketing and consumer acceptance. The fat and unit-weight of market Gulabjamun were found statistically highly significantly different $(\mathrm{p}<0.01)$. The moisture content, percent absorbed sugar, GMD, sphericity of market Gulabjamun were found statistically highly significant $(\mathrm{p}<0.001)$. Apparent density was statistically significant $(p \leq 0.05)$. The fat, moisture and percent absorbed sugar of market Gulabjamun were ranged between $6.47 \pm 0.37$ to $12.32 \pm 1.19 \%, 40.51 \pm 0.70$ to $47.53 \pm 0.42 \%$ d.b. and $12.24 \pm 0.25$ to $37.65 \pm 0.52 \%$, respectively. The geometrical mean diameter, apparent density and unit-weight varied between $3.09 \pm 0.01$ to $3.60 \pm 0.06 \mathrm{~cm}, 1.40 \pm 0.05$ to $1.84 \pm 0.32 \mathrm{~g} / \mathrm{cm}^{3}$ and $24.21 \pm 0.29$ to $44.40 \pm 0.45 \mathrm{~g}$, respectively. Colour characteristics i.e. $L^{*}, a^{*}, b^{*}$ and browning index (BI) market Gulabjamun were found statistically highly significant $(\mathrm{p}<0.001)$. The variation in the values of $L^{*}, a^{*}, b^{*}$ and brownness index was observed to be between $34.70 \pm 0.41$ to $46.46 \pm 0.55,3.92 \pm 0.28$ to $6.50 \pm 0.39$, $2.30 \pm 0.59$ to $11.48 \pm 0.48$, and $2.77 \pm 1.33$ to $36.98 \pm 0.56$, respectively. The hardness, cohesiveness, gumminess, chewiness and resilience were found statistically highly significant $(\mathrm{p}<0.001)$ whereas springiness was found statistically non-significant $(\mathrm{p} \geq 0.05)$. The hardness, springiness, gumminess, chewiness, cohesiveness and resilience ranged between $3.36 \pm 0.56 \mathrm{~N}$ to
\end{abstract}

Dairy Engineering Division, ICAR- National Dairy Research Institute (Deemed University), Karnal - 132 001, Haryana, India

P. Barnwal $(\square)$

Dairy Engineering Division,

ICAR-National Dairy Research Institute (Deemed University),

Karnal-132 001, Haryana, INDIA

Phone: +91-184-2259419(O), +91-8397833349 (M)

Email:pbarnwal@rediffmail.com,psbarnwal@gmail.com
$10.71 \pm 1.66 \mathrm{~N}, 0.52 \pm 0.29$ to $0.88 \pm 0.12,0.86 \pm 0.13 \mathrm{~N}$ to $2.14 \pm 0.28 \mathrm{~N}$, $0.44 \pm 0.24 \mathrm{~N}$ to $1.88 \pm 0.30 \mathrm{~N}, 0.18 \pm 0.01$ to $0.25 \pm 0.01$ and $0.24 \pm 0.01$ to $0.35 \pm 0.02$, respectively. It was observed that the size of market Gulabjamun (3.09 \pm 0.01 to $3.60 \pm 0.06 \mathrm{~cm})$ may be taken as 3.0-3.6 $\mathrm{cm}$ for development of process equipments for Gulabjamun manufacturing.

Keywords: Colour, Gulabjamun, Market, Sphericity, Texture

\section{Introduction}

India is the largest milk producing country in the world with about $19 \%$ contribution in total world milk production. The India's total milk production is estimated to have increased to 187.7 million tonne (MT) during year 2018-19 from 176.35 million tonnes during the year 2017-18 (NDDB, 2019). About half of total milk produced, is consumed in the liquid form and the remaining half is used for manufacturing of various milk products such as ghee, curd, butter, khoa and khoa based products, paneer, cheese, chhana and chhana based products, ice cream and milk powders. A traditional Indian dairy product (TIDP) refers to the products which are indigenous to India and some Asian countries such as Nepal, Bangladesh and Pakistan (Aneja et al. 2002). The various efforts towards its manufacturing including heat desiccation, heat coagulation, fermentation and use of different ingredients resulted into quality products and there are number of sweetmeats (TIDPs), their varieties and brands, available in the Indian market.

Gulabjamun is the fat deep fried and sugar soaked traditional dairy product popular throughout India. Traditionally, it is prepared by producing the homogeneous dough mass, by proper mixing and kneading of Khoa, Maida, and baking powder. Maida is used as binding agent which and it helps to prevent disintegration of Gulabjamun balls at time of frying. The balls prepared from dough are deep-fat fried in frying medium (ghee or refined vegetable oil) until a golden brown colour obtained and subsequently soaked into sugar syrup. Deep-fat frying is a very complex process. It is industrially important food processing operation which increases the acceptability of a food product. The fried food undergoes different properties changes like textural and chemical changes etc. The moisture and fat content of finished product significantly depends upon frying conditions 
such as frying time and frying temperature. In general, the desirable characteristics of Gulabjamun are brown colour, smooth and spherical shape, soft and slightly spongy body (free from lumps), uniform granular texture with pleasant cooked flavour (Vasava et al. 2018). There are mainly two key processes, which are very important in Gulabjamun production i.e. frying of Gulabjamun balls and it's soaking in sugar syrup (after frying of balls). The deep fat frying and sugar soaking of Gulabjamun are most important with respect to its chemical, physical and textural properties.

The characteristics of market sample of various Indian dairy products have been reported by several researchers in published literature such as paneer (Rajorhia et al. 1984; Goyal et al. 2007; Desale et al. 2009; Godbole et al. 2013; Peter et al. 2015; Ranjan Naik et al. 2016), Rasogolla (Desai et al. 1993; Srinivasa et al. 2017), brown peda (Londhe and Pal, 2008), Halvasan (Patel et al. 2010), Dodaburfi (Chawla et al. 2011), KhoaJalebi (Jayaraj and Pagote, 2012), Thabdi (Patel et al. 2012), kheer mohan (Meena et al. 2014) and Khoa-peda (Singh et al. 2018). However, the characteristics of market sample of Gulabjamun are rarely or not reported in published literature.

The characteristics of any food are very important parameters for food processing operation, heat and mass transport processes, food transport and handling, and for design of process, modelling and optimization. It will be useful for designing particular equipment or determining the behaviour of the product during its handling. The present study was undertaken to investigate the selected physico-chemical, colour and textural characteristics of the different brands of market Gulabjamun.

\section{Material and Methods}

\section{Collection of Market Gulabjamun Samples}

The various brands of Gulabjamun are being manufactured in different parts of India. These are being marketed throughout India in small tin cans or other appropriate packaging materials. For present study, different brands of Gulabjamun, manufactured in Nagpur (Maharashtra), Bengaluru (Karnataka), Bikaner (Rajasthan), New Delhi regions along with Karnal (local market), were procured from Delhi and Karnal market. The market Gulabjamun samples of different brands were collected as fresh as available in the market. The market samples of Gulabjamun were designated as M1, M2, M3 and M4 for established brands in India whereas M5 and M6 for sample from local market of Karnal, Haryana, India.

\section{Physico-Chemical characteristics}

Some physico-chemical characteristics, such as fat, moisture, percent absorbed sugar, geometrical mean diameter (GMD), sphericity, apparent density and unit-weight, of Gulabjamun were determined.
Fat

Fat content of the samples was estimated using Mojonnier method (BIS, 1981). The fat in the samples was calculated by following equation:

$$
\operatorname{Fat}(\%)=\left(\frac{W_{d}-W}{W_{s}}\right) \times 100
$$

Where, $W_{s}$ is the weight of the material taken initially for the test (g), $W_{d}$ is the weight of the dish with the material after drying $(\mathrm{g})$, and $W$ is the weight of the empty dish $(\mathrm{g})$.

\section{Moisture}

The moisture content in samples was estimated by the gravimetric method (AOAC, 2005). Following expression was used for determination of moisture on dry basis (\% d.b.): '

$$
\text { Moisture (\% d.b. })=\left(\frac{W_{s}-W_{d}}{W_{d}-W}\right) \times 100
$$

Where, $W_{s}$ is the initial weight of the dish with sample $(\mathrm{g}), W_{d}$ is the final weight of the dish with the sample after drying $(\mathrm{g})$, and $\mathrm{W}$ is the weight of the empty dish $(\mathrm{g})$.

\section{Percent absorbed sugar}

Initial weight of Gulabjamun was measured using digital weighing balance. Gulabjamun was then placed on a plate and $5 \mathrm{~kg}$ weight was applied on plate. After $5 \mathrm{~min}$, the weight of pressed or final Gulabjamun was taken. Percentage of absorbed sugar syrup was calculated using following equation (Mohanta, 2014).

$$
\text { Absorbed sugar }(\%)=\frac{W_{1}-W_{2}}{W_{1}}
$$

Where, $W_{1}$ is the weight of Gulabjamun $(\mathrm{g})$ and $W_{2}$ is the weight of Gulabjamun after weight is applied ( $\mathrm{g})$.

\section{Geometrical mean diameter (GMD):}

The major, intermediate and minor dimensions of Gulabjamun samples were measured as A, B and C, respectively by using a digital vernier calliper (make: Mitutoyo; range: 0-150mm; least count: $0.1 \mathrm{~cm}$ ). The size of the Gulabjamun, in terms of geometrical mean diameter (GMD), was computed using standard equation (Srinivasa et al. 2017; Barnwal et al. 2017):

$$
G M D=(A \times B \times C)^{1 / 3}
$$




\section{Sphericity}

Sphericity $(\Phi)$ may be referred as the ratio of GMD to the major linear dimension, i.e., length (A). It was computed using the following equation (Srinivasa et al. 2017; Barnwal et al. 2017):

$$
\text { Sphericity, } \phi=\frac{G M D}{A}=\frac{(A \times B \times C)^{1 / 3}}{A}
$$

\section{Apparent density ( $\left.\rho_{\text {app }}\right)$}

The apparent density $\left(\rho_{\text {app }}\right)$ of the market Gulabjamun sample was computed as mass per unit volume from the following equation:

$$
\rho_{a p p}=\frac{W}{\left(\frac{4}{3} \pi R^{3}\right)}
$$

Where $\mathrm{W}$ is the weight of Gulabjamun $(\mathrm{g})$ and $\mathrm{R}$ is the radius $(0.5 \times \mathrm{GMD})$ of Gulabjamun (cm).

\section{Unit Weight of the Gulabjamun}

A precision electronic balance (model: KERRO BL 3003; capacity: up to $300 \mathrm{~g}$; least count: $0.001 \mathrm{~g}$ ) was used to measure unit weight of the market Gulabjamun (Srinivasa et al. 2017).

\section{Colour characteristics}

The consumer acceptability of Gulabjamun is very important and it depends upon the crust colour of it. The colour of market samples Gulabjamun was measured using a computer based image analysis technique (Minz et al. 2018). The sample was transferred into wide petri-dish and images of sample were captured in colour desk instrument which was based on reflectance spectroscopy technique. The digital images were processed using Scilab program to compute colour values. This colour value was obtained in terms of lightness, "CIE $L$ " ranging from zero (black) to 100 (white), "CIE $a$ " ranging from +60 (red) to -60 (green) and "CIE $b$ " ranging from +60 (yellow) to -60 (blue). The browning index (BI) value of Gulabjamun was calculated using by following relation (Srinivasa et al. 2017; Barnwal et al. 2017).

$$
\begin{aligned}
& B I=\left[\frac{100 \times(x-0.31)}{0.17}\right] \\
& \text { Where, } \quad x=\frac{\left(a^{*}+1.75 \times L^{*}\right)}{\left(5.645 \times L^{*}+a^{*}-3.012 \times b^{*}\right)}
\end{aligned}
$$

\section{Textural characteristics}

Texture profile of Gulabjamun was determined by using texture analyser (TA-XT2i; M/s Stable micro systems; Software: Texture Expert Exceed, Version: 2.55), fitted with a $25 \mathrm{~kg}$ load cell and calibrated with $5 \mathrm{~kg}$ standard dead weight prior to use (Kumar et al. 2006). Gulabjamun was compressed twice in a reciprocating motion to obtain a two-bite texture profile curve using a double compression test. The various test parameters, used throughout the study, for whole, uncut Gulabjamun sample were P-75 compression probe, $1 \mathrm{~mm} / \mathrm{s}$ probe pre-test speed, $0.5 \mathrm{~mm} / \mathrm{s}$ test speed, $10 \mathrm{~mm} / \mathrm{s}$ post-test speed, $7.5 \mathrm{~mm}$ distance (compression) and $25 \pm 1{ }^{\circ} \mathrm{C}$ maintained sample temperature. The obtained texture profile curve (TPA) was used to determine the hardness, springiness, cohesiveness, gumminess, chewiness and resilience of the tested market Gulabjamun samples.

\section{Statistical analysis}

The experimental data for different characteristics such as physico-chemical, colour and textural characteristics were analysed statistically. The Analysis of Variance (ANOVA) for all various characteristics of market Gulabjamun were analyzed by SPSS (v. 15.0) software and 2D-graphs of various characteristics were prepared by using Microsoft Excel-2007 software.

\section{Results and Discussion}

\section{Physico-chemical characteristics of market Gulabjamun samples}

The fat content of market Gulabjamun samples (M1, M2, M3, M4, M5 and M6) were found statistically highly significantly different $(\mathrm{p}<0.01)$ with each other (Table 1). It varied from $6.47 \pm 0.37 \%$ (M3) to $12.32 \pm 1.19 \%$ (M6). The fat content of Gulabjamun on drained weight basis was reported as about $10 \%$ (Aneja et al. 2002). The variation in fat content of Gulabjamun, prepared using khoa of Buffalo milk blending with sweet corn milk, was found to be 10.26-14.98\% (Patil et al. 2017). The market Gulabjamun samples M5 and M6 were observed to be in nearly this range whereas M1, M2, M3 and M4 had lesser fat content. Minhas et al. (1985) reported that the fat content range 9.9 to $16.7 \%$ of Gulabjamun (prepared by different formulations mix, different frying temperature range and different soaking time range) was more than the fat content of studied market Gulabjamun. The moisture content of studied market Gulabjamun samples were found statistically highly significant $(\mathrm{p}<0.001)$ among each other (Table 2). The moisture content of samples M3, M4, and M5 were statistically at par with each other. The moisture content of M3, M5 and M6 were statistically at par with each other whereas that of M1, M3, M4 and M6 was statistically different with each other (Figure 1). It varied from $40.51 \pm 0.70 \%$ d.b. (M6) to $47.53 \pm 0.42 \%$ d.b. (M2). The variation of moisture content of Gulabjamun, prepared by using different 
Fig. 1 Moisture, percent absorbed sugar, unitweight and $L^{*}$ values of Market Gulabjamun

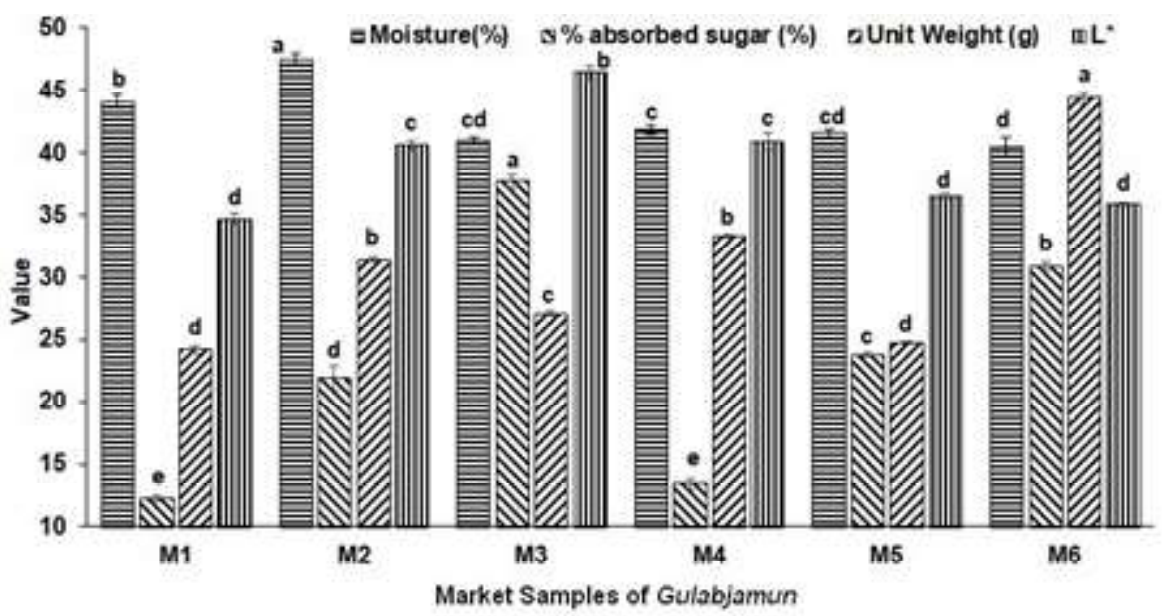

Table 1 Fat, apparent density, b*, browning Index and hardness of Market Gulabjamun

\begin{tabular}{|c|c|c|c|c|c|}
\hline $\begin{array}{l}\text { Market } \\
\text { Gulabjamun }\end{array}$ & $\begin{array}{l}\text { Fat } \\
(\%)\end{array}$ & $\begin{array}{l}\text { Apparent } \\
\text { density }\left(\mathrm{g} / \mathrm{cm}^{3}\right)\end{array}$ & $b^{*}$ & $\begin{array}{l}\text { Browning } \\
\text { Index }\end{array}$ & $\begin{array}{l}\text { Hardness } \\
\text { (N) }\end{array}$ \\
\hline$\overline{\mathrm{M} 1}$ & $8.53^{\mathrm{cd}} \pm 0.43$ & $1.56^{\mathrm{a}} \pm 0.04$ & $3.17^{\mathfrak{c}} \pm 0.09$ & $17.52^{c} \pm 0.80$ & $5.78^{b c} \pm 0.28$ \\
\hline $\mathrm{M} 2$ & $9.59^{b c} \pm 0.27$ & $1.84^{a} \pm 0.32$ & $5.63^{b} \pm 0.27$ & $26.21^{\mathrm{b}} \pm 1.32$ & $7.15^{\mathrm{ab}} \pm 0.38$ \\
\hline M4 & $7.63^{\mathrm{de}} \pm 0.35$ & $1.84^{a} \pm 0.24$ & $5.39^{b} \pm 0.02$ & $24.53^{\mathrm{b}} \pm 1.63$ & $9.95 \pm 1.63$ \\
\hline M5 & $10.29^{b} \pm 0.37$ & $1.40^{a} \pm 0.05$ & $-2.30^{\mathrm{d}} \pm 0.59$ & $2.77^{\mathrm{d}} \pm 1.33$ & $7.61^{\mathrm{ab}} \pm 2.22$ \\
\hline $\mathrm{DF}$ & 5 & 5 & 5 & 5 & 5 \\
\hline SS & 64.285 & 0.519 & 307.255 & 1918.404 & 109.474 \\
\hline MS & 12.857 & 0.104 & 64.451 & 383.681 & 21.895 \\
\hline F-Value & 36.782 & 3.479 & 471.250 & 295.914 & 11.958 \\
\hline Prob & $<0.0001 * * *$ & $0.036^{*}$ & $<0.0001 * * *$ & $<0.0001 * * *$ & $<0.0001 * * *$ \\
\hline
\end{tabular}

Mean values with the same superscript are not significantly different; $* p \leq 0.05 ; * * * p \leq 0.001 ; n=3$

level of Khoa and Paneer, were 35.07-37.50\% (Singh et al. 2019), which is slightly lower as compared to moisture content of studied market Gulabjamun. The percent absorbed sugar in Gulabjamun of market samples were found statistically highly significant $(\mathrm{p}<0.001)$ with sample type (Table 2$)$ and their values (Figure 1) ranged between $12.24 \pm 0.25 \%$ (M1) to $37.65 \pm 0.52 \%$ (M3). The percent absorbed sugar of M1, M4 and M5 were statistically at par with each other whereas M2, M3 and M6 were not statistically at par with each other. The fat, moisture and percent absorbed sugar were found maximum for M6, M3 and M1, respectively whereas minimum for M2, M6 and M3, respectively (Table 1, Figure 1).

The GMD of Market Gulabjamun samples were found statistically highly significant $(\mathrm{p}<0.001)$ with sample type (Table 2$)$ and the values (Figure 2) varied from $3.09 \pm 0.01 \mathrm{~cm}$ (M1) to $3.60 \pm 0.06 \mathrm{~cm}$ (M6). The GMD of samples M1, M3, M4 and M5 were statistically at par with each other whereas that of M2 and M6 was statistically at par with each other (Figure 2). The variation in diameter of market Rasogolla was $2.7 \pm 0.0$ to $3.9 \pm 0.1 \mathrm{~cm}$ (Srinivasa et al. 2017), which was similar to the GMD of market Gulabjamun. The sphericity of market Gulabjamun samples were found statistically highly significant $(\mathrm{p}<0.001)$ with sample type (Table 2$)$ and it varied (Figure 3) from 0.94 (M1) to 0.97 (M6). The sphericity of market Gulabjamun samples M1, M2, M3 and M4 were statistically at par with each other whereas M1 was statistically different with M5 and M6 samples (Figure 3). The sphericity of Gulabjamun may depend on frying temperature of the balls and at lower temperature; balls obtain soft crust which may not retain its shape (spherical). The sphericity of any food near unity (1.00) may be considered as a spherical product for modelling of heat and transfer processes occurring during product production. The apparent density of studied market Gulabjamun samples ranged from $1.40 \pm 0.05 \mathrm{~g} / \mathrm{cm}^{3}\left(1 \mathrm{~g} / \mathrm{cm}^{3}=1000 \mathrm{~kg} / \mathrm{m}^{3}\right)$ to $1.84 \pm 0.32 \mathrm{~g} / \mathrm{cm}^{3}$ i.e. M5 (minimum) to M2 (maximum), respectively (Table 1). It was statistically significant $(\mathrm{p} \leq 0.05)$ with sample type (Table 1$)$. Franklin et al. (2013) found that the average apparent densities of conventionally fried Gulabjamun at different temperatures i.e. 125,135 and $145^{\circ} \mathrm{C}$ were $0.827,0.808$ and $0.775 \mathrm{~g} / \mathrm{cm}^{3}$, respectively. The unit-weight of market Gulabjamun samples were found 
Fig. 2 Geometric mean diameter (GMD) and $a^{*}$ values of Market Gulabjamun

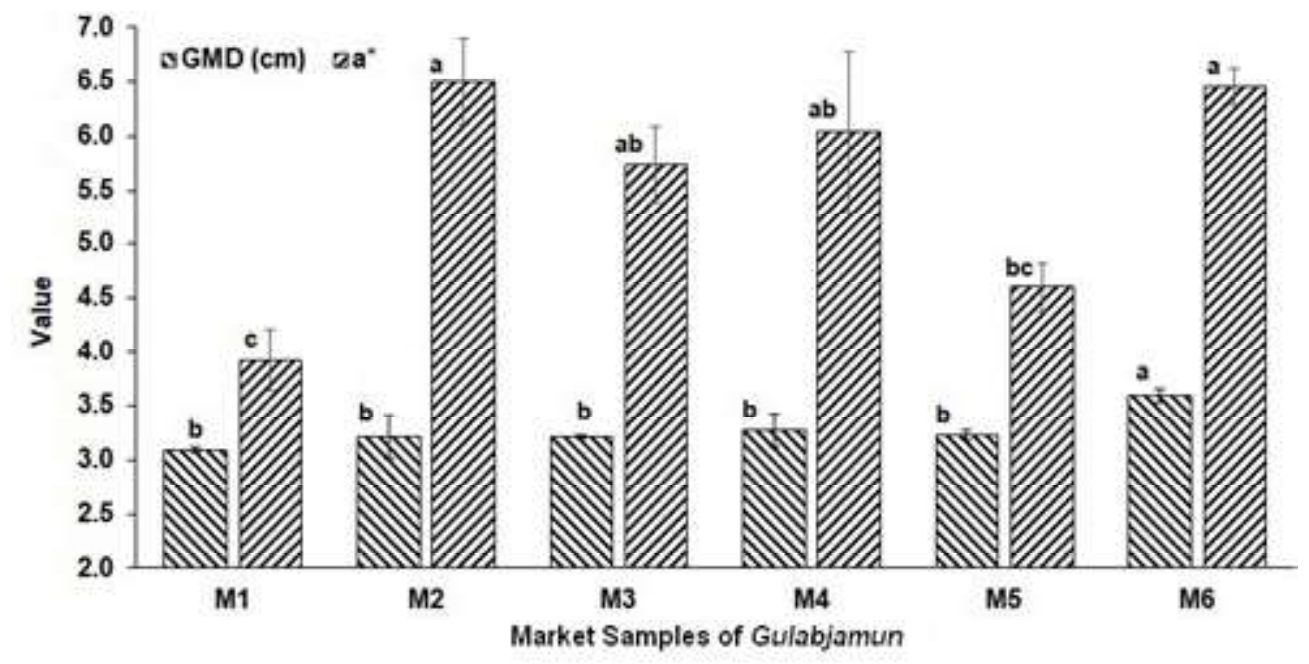

Table 2 ANOVA for some physical and colour characteristics of Market Gulabjamun

\begin{tabular}{lllllll}
\hline $\begin{array}{l}\text { Market } \\
\text { Gulabjamun }\end{array}$ & $\begin{array}{l}\text { Moisture } \\
(\%)\end{array}$ & $\begin{array}{l}\text { Percentage } \\
\text { Absorbed sugar }(\%)\end{array}$ & $\begin{array}{l}\text { GMDericity } \\
(\mathrm{cm})\end{array}$ & $\begin{array}{l}L^{*} \\
\text { (fraction) }\end{array}$ & $a^{*}$ \\
\hline DF & 5 & 5 & 5 & 5 & 5 & 5 \\
SS & 105.188 & 1454.819 & 0.440 & 0.002 & 290.118 & 16.630 \\
MS & 21.040 & 290.964 & 0.088 & 0.000 & 58.024 & 3.326 \\
F-Value & 96.016 & 1016.290 & 7.328 & 4.498 & 282.659 & 20.137 \\
Prob & $<0.0001^{* * *}$ & $<0.0001^{* * *}$ & $<0.01^{* *}$ & $0.015^{*}$ & $<0.0001^{* * *}$ & $<0.0001^{* * *}$ \\
\hline
\end{tabular}

Mean values with the same superscript are not significantly different; ${ }^{*} p \leq 0.05 ;{ }^{* *} p \leq 0.01 ; * * * p \leq 0.001 ; n=3$

Fig. 3 Sphericity, springiness, gumminess, and chewiness of Market Gulabjamun

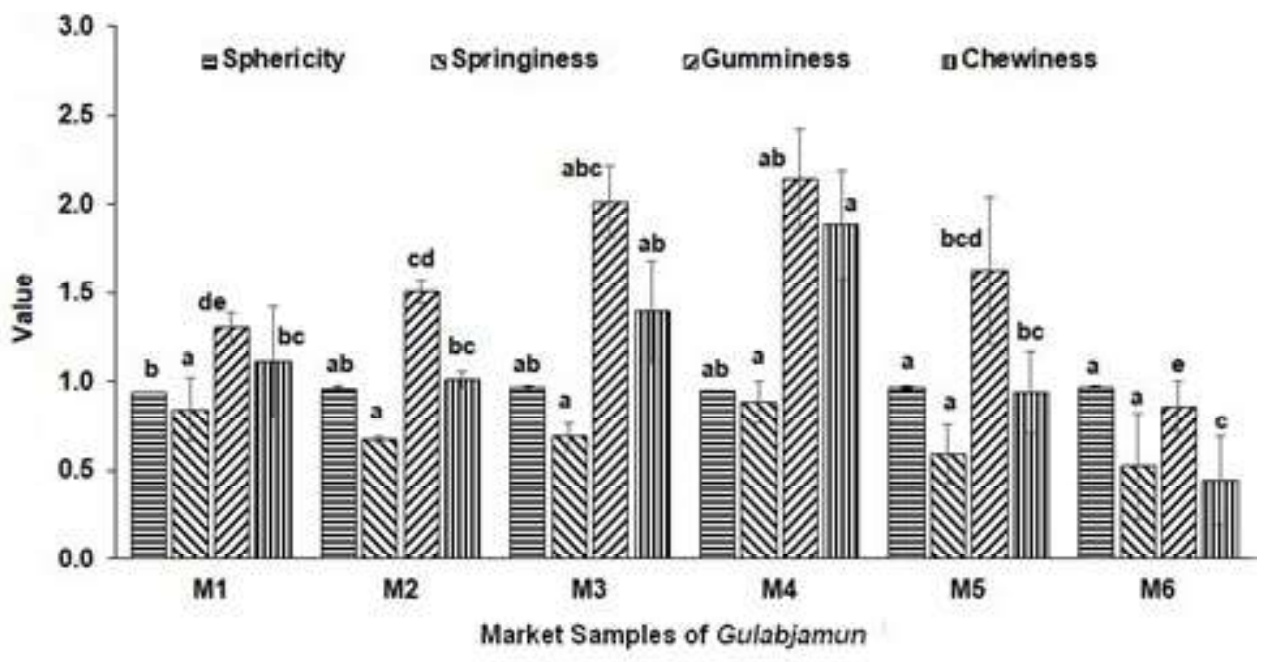

statistically highly significant $(\mathrm{p} \leq 0.01)$ with sample type (Table 3 ) and their values (Figure 1) varied from $24.21 \pm 0.29 \mathrm{~g}$ (M1) to $44.40 \pm 0.45 \mathrm{~g}$ (M6). The unit-weight of Gulabjamun sample M1 and M5 were found statistically at par with each other whereas that of M2 and M4 was statistically at par with each other (Figure 1). The samples M3 and M6 were statistically different with each other.

\section{Colour characteristics of market Gulabjamun}

The colour parameters of market samples Gulabjamun were studied using image analysis. Colour characteristics i.e. $L^{*}$ and $a^{*}$ (Table 2), $b^{*}$ and browning index (Table 1) of studied market Gulabjamun samples were found statistically highly significant $(\mathrm{p}<0.001)$ with sample type (Table 3$)$. The values of $L^{*}$ (Figure 1$)$ ranged (minimum to maximum) between $34.70 \pm 0.41$ (M1) to $46.46 \pm 0.55$ (M3). The $a^{*}$ values ranged (minimum to maximum) between $3.92 \pm 0.28$ (M1) to $6.50 \pm 0.39$ (M2). The values of $b^{*}$ and 
Fig. 4 Cohesiveness and resilience of Market Gulabjamun

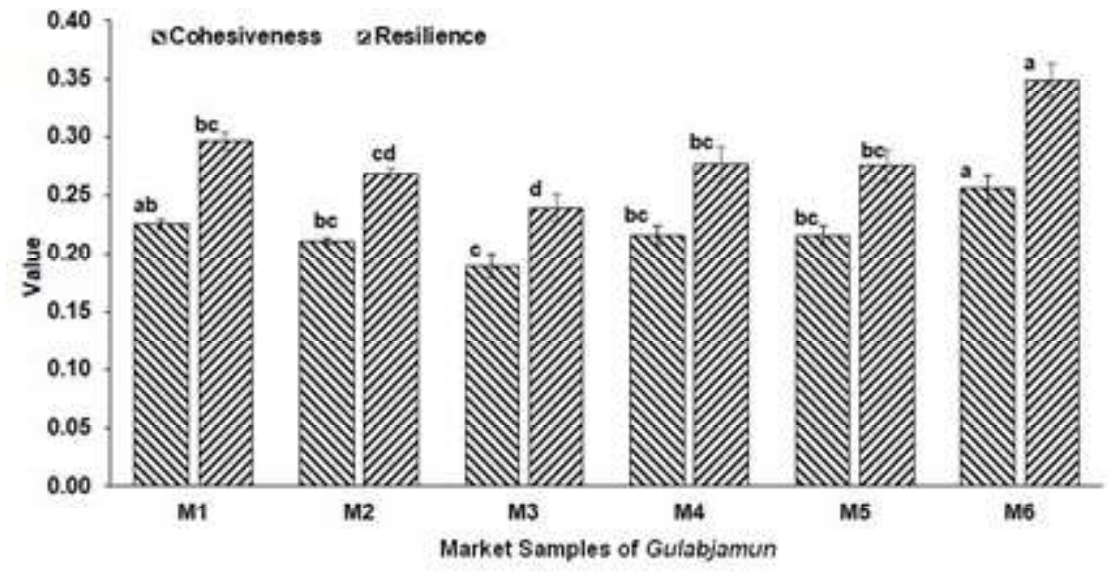

Table 3 ANOVA for some textural characteristics and unit weight of Market Gulabjamun

\begin{tabular}{lllllll}
\hline $\begin{array}{l}\text { Market } \\
\text { Gulabjamun }\end{array}$ & Springiness & Cohesiveness & $\begin{array}{l}\text { Gumminess } \\
(\mathrm{N})\end{array}$ & $\begin{array}{l}\text { Chewiness } \\
(\mathrm{N})\end{array}$ & Resilience & $\begin{array}{l}\text { Unit- weight } \\
(\mathrm{g})\end{array}$ \\
DF & 5 & 5 & 5 & 5 & 5 & 5 \\
SS & 0.292 & 0.007 & 3.308 & 3.497 & 0.20 & 1242.454 \\
MS & 0.058 & 0.001 & 0.662 & 0.699 & 0.004 & 207.076 \\
F-Value & 2.070 & 24.407 & 12.260 & 10.700 & 29.584 & 330.459 \\
Prob & $0.140^{\text {NS }}$ & $<0.0001 * * *$ & $<0.0001 * * *$ & $<0.0001 * * *$ & $<0.0001 * * *$ & $<0.01 * *$ \\
\hline
\end{tabular}

Mean values with the same superscript are not significantly different; $N S=$ non-significant; $* * p \leq 0.01 ; * * * p \leq 0.001 ; n=3$

browning index ranged (minimum to maximum) between $-2.30 \pm 0.59$ (M5) to $11.48 \pm 0.48$ (M3), and 2.77 \pm 1.33 (M5) to $36.98 \pm 0.56$ (M3), respectively (Table 1$)$. The $L^{*}$ values were found statistically at par with each other (Figure 1) for market Gulabjamun samples (i) M2 and M4 (ii) M5 and M6, and (iii) M1 and M6. The M3 sample showed maximum $L^{*}$ value. It was reported that lightness value $\left(L^{*}\right)$ of Gulabjamun Balls depends upon frying temperature of Gulabjamun Balls (deep fat frying). Lightness value $\left(L^{*}\right)$ of the Gulabjamun Balls (deep fat frying) was ranged from 23.48 to 79.86 which was decreased gradually with increasing frying time (Kumar et al. 2006). In case of $a^{*}$ values of market Gulabjamun samples, the M2, M3, M4 and M6 were found statically at par with each other whereas samples M1 and M5 also found statically at par with each other (Figure 2). The $b^{*}$ values and browning index were found statistically at par with each other for (i) M1 and M6, and (ii) M2 and M4 (Table 1) in market Gulabjamun samples.

\section{Textural characteristics of market Gulabjamun}

The hardness, cohesiveness, gumminess, chewiness and resilience were found statistically highly significant $(\mathrm{p}<0.001)$ whereas springiness was found statistically non-significant $(\mathrm{p} \geq 0.05$ ) with sample type (Tables 1 and 3 ). The values for hardness (Table 1) ranged (minimum to maximum) between $3.36 \pm 0.56 \mathrm{~N}$ (M6) to $10.71 \pm 1.66 \mathrm{~N}$ (M3). The values for springiness, gumminess and chewiness ranged (minimum to maximum) between, $0.52 \pm 0.29$ (M6) to $0.88 \pm 0.12$ (M4), $0.86 \pm 0.13$ $\mathrm{N}$ (M6) to $2.14 \pm 0.28 \mathrm{~N}$ (M4) and $0.44 \pm 0.24 \mathrm{~N}$ (M6) to $1.88 \pm 0.30 \mathrm{~N}$ (M4), respectively (Figure 3 ). The values for cohesiveness and resilience ranged (minimum to maximum) between, $0.18 \pm 0.01$ (M3) to $0.25 \pm 0.01$ (M6), and $0.24 \pm 0.01$ (M3) to $0.35 \pm 0.02$ (M6), respectively (Figure 4 ). The hardness was found statistically at par with each other for market Gulabjamun samples (i) M3, M4 and M5 (ii) M1, M2, and M5, and (iii) M1 and M6 (Table 1). In market Gulabjamun samples, the cohesiveness and resilience were found statistically at par with each other for (i) M1, M2, M4, and M5, and (ii) M2 and M3 (Figure 4). For market Gulabjamun samples, the gumminess was found statistically at par with each other for (i) M2, M3, M4, and M5 (ii) M1, M2 and M5, and (iii) M1 and M6 (Figure 3). The chewiness was observed statistically at par with each other for market Gulabjamun samples for (i) M1, M2, M3, and M5 (ii) (i) M1, M2, M5, and M6, and (i) M3 and M4 (Figure 3). Aneja et al. (2002) reported that the hardness (N), springiness $(\mathrm{mm})$, cohesiveness, gumminess $(\mathrm{N})$, chewiness (N.mm) of Gulabjamun as $14.09 \mathrm{~N}, 7.88 \mathrm{~mm}, 0.123,1.75 \mathrm{~N}$, and 14.21 N.mm, respectively. So, the hardness, springiness, cohesiveness and chewiness of Gulabjamun were found less than market sample of Gulabjamun.

Therefore, there was statistically significant difference was observed in the characteristics of selected brands of market Gulabjamun samples which may be due to the variations in 
various steps at processing, packaging, storage and distribution stages of studied market Gulabjamun samples.

\section{Conclusions}

The various quality characteristics i.e. physico-chemical, colour and textural characteristics of six brands of Gulabjamun were determined and statistical analysis was carried out. The fat and unit-weight of market Gulabjamun were found statistically highly significantly different . The moisture content, percent absorbed sugar, GMD, sphericity of studied market Gulabjamun samples were found statistically highly significant. Apparent density was statistically significant. The hardness, cohesiveness, gumminess, chewiness and resilience were found statistically highly significant whereas springiness was found statistically nonsignificant ( $\mathrm{p}>0.05)$. The size of market Gulabjamun (3.09 \pm 0.01 to $3.60 \pm 0.06 \mathrm{~cm}$ ) may be taken as $3.0-3.6 \mathrm{~cm}$ for development of process equipments for Gulabjamun production.

\section{Acknowledgement}

The authors acknowledge fellowship and infrastructure received from ICAR-NDRI, Karnal to carry out the research work.

\section{References}

Aneja RP, Mathur BN, Chandan RC, Banerjee AK (2002) Technology of Indian milk products: Handbook on Process Technology Modernization for Professionals, Entrepreneurs and Scientists. Dairy India Yearbook, 109-111

AOAC (ed) (2005) Official methods of analysis of AOAC international. Washington D.C.

Barnwal P, Kumar P, Singh KK, Mohite, AM (2017) Selected engineering properties of cryogenic and ambient ground black pepper. J Food Process Preserv 41: e12899

BIS: (1981) (SP: 18) ISI Handbook of Food Analysis. Part XI: Dairy Products. Bureau of Indian Standards, New Delhi, India

Chawla R, Patil GR, Singh AK (2011) Physicochemical and textural attributes of market sample of Dodaburfi. Dairy Foods Int 1:176183

Desai HK, Gupta SK, Patel AA, Patil GR (1993) Texture of rasogolla, effect of composition and variety in market samples. Indian J Dairy Sci 46: 123-127

Desale RJ, Dhole PT, Deshmukh AR, Nimase RG (2009) Studies on quality evaluation of market paneer. Asian J Anim Sci 4: 73-74

Franklin MEE, Pushpadass HA, Ravindra MR, Rao KJ, Nath BS (2013) Modeling the heat and mass transfer during frying of Gulabjamun. J Food Process Preserv 38: 1939-1947

Godbole S, Dabholkar P, Pachbudhe A (2013) Evaluation of bacteriological quality of Indian cheese (paneer) sold in Nagpur city. J Global Biosci 2: 53-56

Goyal RK, Singh PK, Goyal SK (2007) Studies on quality evaluation of market paneer. Int J Agric Sci 3: 165-167

Jayaraj RK, Pagote CN (2012) Khoa Jalebi, a unique traditional product of central India, Indian J Traditional Knowl 11: 96-102

Kumar JA, Singh RRB, Patel AA, Patil GR (2006) Kinetics of colour and texture changes in Gulabjamun balls during deep fat frying. LWTFood Sci Technol 39: 827-833
Londhe GK, Pal D (2008) Studies on the quality evaluation of market samples of brown peda. Indian J Dairy Sci 61: 347-352

Meena GS, Gupta VK, Khetra Y, Raghu HV, Khurana S (2014) Characterization of market kheer mohan. Indian J Dairy Sci 67: 380-386

Minhas KS, Rangi AS, Sindu JS (1985) Indigenous Milk Products-II. Effect of Recipe on the Chemical Composition of Gulabjamun. Journal Food Sci Technol 22: 244-247

Minz PS, Sawhney IK, Saini CS (2018) Algorithm for automatic calibration of color vision system in foods. J Food Meas Charact 12: 1-8

Mohanta B, Shrivastava SL (2014) Optimization of process parameters for preparation of Rasogolla -an Indian dairy product at atmospheric pressure. Asia Pacific J Res 1:47-56

NDDB (2019) Annual Report 2018-2019. National Dairy Development Board, Anand, Gujarat

Patel HG, Prajapati JP, Solanky MJ, Prajapati PS, Soni D (2010) Characterization of Halvasan from market and a process of its manufacture. Indian J Dairy Sci 63:376-380

Patel KN, Patel HG, Prajapati JP, Prajapati PS (2012) Characterization of market Thabdi. Indian J Dairy Sci 5:122-128

Patil S, Padghan PV, Patil RA (2017) Physico-chemical properties of Gulabjamun prepared from khoa of Buffalo milk blended with sweet corn milk. J Pharmacogn Phytochem 6: 69-72

Peter A, Sarathchandra G, Manimehalai N, Athmaselvi KA (2015) Assessment of microbiological quality and aflatoxin levels of paneer marketed in Chennai, India. The Int J Sci Technol 3:118-125

Rajorhia GS, Dharmpal, Arora KL (1984) Quality of Paneer marketed in Karnal and Delhi. Indian J Dairy Sci 37:274-276

Ranjan Naik R, Palani Dorai R, Prasad Kumar P, Kumar K (2016) Qualitative analysis of market paneer of Odisha. Indian J Dairy Sci 69: $680-685$

Singh A, Kishor K, Prasad GMS, Majumder S, Priyanka (2019) Studies on Physic-Chemical Quality Parameters of Gulabjamun Prepared by Different Level of Khoa and Paneer. European J Biotechnol Biosci 7: $44-46$

Singh G, Sawhney IK, Singh M, Minz PS (2018) Determination of engineering properties of market samples of khoa-peda for its application in process mechanization. Indian J Dairy Sci 71: 115120

Srinivasa K, Barnwal P, Singh P (2017) Selected physical, colour and textural characteristics of market Rasogolla. Indian J Dairy Sci 70: $155-160$

Vasava NM, Paul P, Pinto S, Modha H (2018) Studies on rheological and sensory properties of gluten-free Gulabjamun during storage. Int J Chem Stud 6: 1840-1848 